\title{
Orthographic correction of the name Arisaema arunachalensis A.Nangkar, A.P. Das \& H.Tag and few comments on its morphology
}

\author{
Atek Nangkar, A. P. Das and Hui Tag 1 \\ Plant Systematic and Ethnobotanical Research Laboratory, Department of Botany, \\ Rajiv Gandhi University, Rono Hills, Doimukh-791112, Arunachal Pradesh, India \\ ${ }^{1}$ Corresponding author, e-mail: huitag2008rgu@gmail.com
}

[Received 19.03.2018; Accepted 21.11.2017; Published 31.12.2017]

We published the name of a new species of Arisaema Schott in Pleione [11(2): $480-484$. 2017] as A. arunachalensis A.Nangkar, A.P. Das \& H.Tag. The construction is with an orthographic error as the generic name is in neuter gender. So, the corrected form of the name will be:

Arisaema arunachalense A.Nangkar, A.P. Das \& H.Tag [ut A. arunachalensis].

The Type specimens, description, etymology, ecology and distribution relating to this species and its name will remain same as it was already published (Nangkar et al. 2017). However, the Types are presented again for the convenience of readers:

TYPES: INDIA, Arunachal Pradesh, East Siang District, Pasighat, $560 \mathrm{~m}$, May 08, 2015, latitude $28^{\circ} 08^{\prime} 34.0^{\prime \prime} \mathrm{N}$ and longitude $095^{\circ} 15^{\prime} 56.8^{\prime \prime} \mathrm{E}$, A. Nangkar \& Hui Tag 026 (HOLOTYPUS: ASSAM); A. Nangkar \& Hui Tag 028 (PARATYPUS: HAU).

However, as pointed by Dr. Pascal Bruggman, the structure of the old tuber remains wrinkled at the flowering stage of the plant and the surface of new tuber is smooth.

Also, A. echinatum is a stoloniferous species but in $A$. arunachalense stolons are not formed in any stage of its life.

Authors are thankful to Dr. Pascal Bruggman for his useful comments on the name and some morphological features of the species.

\section{LITERATURE CITED}

Nangkar, Atek; Das, A.P. \& Tag, Hui 2017. Arisaema arunachalensis A.Nangkar, A.P. Das \& H.Tag, sp. nov. (Araceae) from the Arunachal Region of the Indian Himalaya. Pleione 11(2): 480 - 484. 